\title{
Poisoning the Well of Art Education
}

\section{Michelle Marder Kamhi}

In his inaugural speech to the nation, President Biden rightly emphasized that in our quest for national unity, we need to "defend the truth and defeat the lies.” Sadly, however, he subsequently perpetuated one of the most consequential lies now in wide circulation-the notion that America is entrenched in "systemic racism." That lie is gravely poisoning the well of art education, among so many other aspects of American life.

In June 2020, James Haywood Rolling, Jr.-then president-elect of the National Art Education Association (NAEA) and inaugural chair of the organization's Equity, Diversity, \& Inclusion Commission-issued an open letter to art educators “on constructing an anti-racist agenda." Titled "Black Lives Matter" after the radical protest movement, it called for resistance to "the systemic racism that violently impacts the daily lives" of students.

\section{Examining the Lie}

“Systemic racism” implies that racist policies are embedded in our laws and institutions. That claim is patently false, however, as evidenced by Americans having elected a biracial president for two terms and, more recently, a biracial vice president-not to mention blacks serving in the cabinet, in the highest ranks of the armed services, and in various other prominent positions, both public and private. The truth is that the only systemic racism that exists today is in the form of affirmative action measures favoring blacks, among other presumably disadvantaged groups

Rolling, a black professor of arts education at Syracuse University, is undeterred by such facts, or by his own election to high position in his profession (the woman who will succeed him is also black). In his view, any manifestation of racism, however individual, is ipso facto "systemic." And he repeats the

Michelle Marder Kamhi is an independent scholar and critic and co-edits Aristos, an online review of the arts. Her latest book is Bucking the Artworld Tide: Reflections on Art, Pseudo Art, Art Education \& Theory (Pro Arte Books, 2020); www.mmkamhi.com. Kamhi last contributed to Academic Questions with "Beware the Semmelweis Reflex," in the Spring 2021 issue. 
all-too-common claim that any organization "that is not actively [emphasis his] anti-racist is complicit" in allegedly racist outcomes.

What is Rolling's evidence? Predictably, it is "the casual murder of a litany of Black men and women like George Floyd, Breonna Taylor, and Ahmaud Arbery." It has reminded him, he says, of "what it feels like to be exposed, vulnerable, and preyed upon every day." Like others on the left, he thus asserts the prevailing victim narrative, which presumes that the chief cause of such events, as well as of the economic and social disadvantages of blacks, is antiblack racism. In so doing, he is either unaware of, or willfully ignores, the evidence-based alternative explanations offered by numerous conservatives, black as well as white-from Thomas Sowell, Shelby Steele, and Walter Williams to Heather Mac Donald.

As such writers have cogently argued and extensively documented, the primary underlying factor in racial disparities regarding both policing and economic and social outcomes is not white-on-black racism or the system of “white supremacy" that Rolling and others allege. It is, instead, the increasing breakdown of the black family (nearly three of every four black children are now born out of wedlock), which is closely correlated with a high rate of crime among blacks, the primary victims of which are other blacks. Though the left now turns a blind eye to that tragic breakdown, it was first prominently noted decades ago by no less a liberal than Daniel Patrick Moynihan, who clearly recognized its dire consequences. ${ }^{1}$ Moreover, as the conservative writers cited above further argue, the breakdown has been grievously exacerbated by the very welfare programs presumably designed to help disadvantaged blacks.

Yet the lie continues to be compounded at every turn. More than twenty sessions of the NAEA's 2021 (Virtual) Convention were devoted to issues of systemic racism, white supremacy, and racially charged "diversity" issues. One of the many academic presenters of such sessions was Vanessa López from the Maryland Institute College of Art, whose credentials include helping to draft the National Core Arts Standards in Visual Arts and serving as an advisor to the Maryland State Department of Education.

Writing in the March 2021 issue of the journal Art Education, López-a light-skinned but self-described "woman of color"-argues that the "killing" of

1 Daniel P. Moynihan, The Negro Family: The Case for National Action, Office of Policy Planning and Research, U.S. Department of Labor (Washington, D.C., 1965), https://www.dol.gov/general/aboutdol/ history/webid-moynihan. 
George Floyd was for her the ultimate turning point in race relations because “we $A L L$ saw it." No, what we all saw was the highly selective last few moments of Floyd's life circulated by the media. What we all did not see was the full sequence of events leading up to his death. Why? Because the full bodycam video had been withheld by the Minnesota Attorney General who stated that he didn't want to jeopardize a "successful prosecution" of the white officer charged with Floyd's murder.

What the full video showed was that Floyd had behaved erratically during his arrest, had powerfully resisted efforts by officers to get him into their squad car (a former football player, Floyd was 6 feet 4 and weighed 223 pounds), andperhaps most relevant-had repeatedly said "I can't breathe" before being placed in the presumably fatal neckhold. Nor was it widely reported that Floyd had significant underlying conditions, as well as a fatal level of fentanyl (in addition to methamphetamine) in his blood stream. Contrary to the widespread inference that Floyd's breathing difficulty was induced by police restraint, breathing difficulty is commonly associated with fentanyl overdose-although restraint may well have aggravated it.

Even if one accepts Officer Chauvin's April 2021 conviction on various counts of murder and manslaughter as fully justified, the case would not be evidence that America is beset by "systemic racism." Nor would it justify the months of rioting the incident inspired-which took numerous lives and destroyed between one and two billion dollars of property, including that of small, blackowned businesses. Still less would it justify the demonization of all police or the resulting "defund the police" movement, the destructive consequences of which are most felt in disadvantaged black communities. Finally, it would not justify the elevation of Floyd (however tragic his death) - a man with a record of multiple prior arrests and convictions, including one for "aggravated robbery with a deadly weapon"-to a virtual martyr saint in the eyes of the public.

\section{Afrofuturism}

Far from considering such complex realities, art educators like Rolling seem bent on fantasizing about a fabled African past (and present) and an African American future in which blacks will no longer be a minority. His views are shared by Joni Boyd Acuff, for example-a black professor who is graduate studies chair for Arts Administration, Education and Policy at Ohio State University and also serves on the review board of the International Journal of Education and 
the Arts and the Journal of Social Theory in Art Education, among other positions of influence. Acuff recommends "Afrofuturism" as a way of re-conceiving an art curriculum supportive of blacks. ${ }^{2}$ She begins by claiming: "Visions of blackness in America today reflect a society that does not value black existence." She sees only such things as "young Black women slammed to the ground by police officers.” In contrast, I see the black community widely recognized and embraced in TV sitcoms, movies, music, advertising, and sports. I even see numerous images of interracial couples. They remind me how common intermarriage and interracial children have in fact become in our society, ${ }^{3}$ where miscegenation was formerly prohibited in many states. Ironically belying his own claim of "systemic racism," even President Biden has remarked on the frequency of "mixed-race couples" in TV commercials. ${ }^{4}$ This is a clear sign that we are no longer living in the pervasively racist society of the 1860s or even the 1960s-a fundamental truth ignored by “anti-racist” activists.

Moreover, like every other aspect of the "anti-racism" crusade, the obsession with alleged racial bias sees it as a problem unique to "white supremacists.” Tellingly, no thought is given to actual hate crime statistics. According to the FBI, of the 6,406 known offenders in all hate crimes in 2019 (about 55 percent of which were attributable solely to Race/Ethnicity/Ancestry bias), for example, 52.5 percent were white and nearly 24 percent were black or African American. ${ }^{5}$ Given that whites constitute about 73 percent of the total population and blacks 13 percent, whites were underrepresented among hate crime offenders by about 21 percentage points while blacks were overrepresented by nearly 11 percentage points. Such considerations would unduly complicate the desired white-on-black victim narrative, however.

Skewed vision is further evident in Acuff's approval of graffitist JeanMichel Basquiat's challenge to “the invisibility of Black artists in the contemporary artworld.” Invisibility? A hasty search reveals the following blacks either scheduled or previously featured on PBS's Art21 series: Kerry James Marshall (multiple programs), Theaster Gates, Jordan Casteel, Jack Whitten, Doreen

2 Joni Boyd Acuff, "Afrofuturism: Reimagining Art Curricula for Black Existence," Art Education, May 2020, 13-21.

3 According to the Pew Research Center, "Between 2000 and 2010, the number of white and black biracial Americans more than doubled," Multiracial in America, June 11, 2015.

4 "Remarks by President Biden Commemorating the 100th Anniversary of the Tulsa Race Massacre," Greenwood Cultural Center, Tulsa, Oklahoma, June 1, 2021, https://tinyurl.com/h72abesp

5 FBI 2019 Hate Crime Statistics, https://ucr.fbi.gov/hate-crime/2019/hate-crime, esp. Table 1, https:// tinyurl.com/37m7ryaz. Because the larger total number of anti-black incidents (1,930 compared to 666 anti-white incidents) occur within a smaller black cohort, however, blacks are victimized by hate crimes at a higher rate than whites. 
Garner, Kara Walker, Carrie Mae Weems, Rashid Johnson, John Akomfrah, Shaun Leonardo, Kalup Linzy, and Kevin Beasley. In addition, Basquiat was himself featured on PBS's American Masters series and in a 1992 retrospective at the Whitney Museum of American Art. ${ }^{6}$ Many traditional contemporary artists would welcome such invisibility.

Afrofuturism does not simply aim to add black artists to the existing art curriculum. In Acuff's view, it instead regards Africa as if it were "at the forefront of worldwide technological and human advancements." In other words, to counter alleged systemic racism in contemporary America, where slavery was prohibited a century and a half ago (and Jim Crow laws were ended more than half a century ago), students should fantasize about freedom in Africa, which ranks as the "epicenter of modern-day slavery," with some 9 million or more enslaved individuals. ${ }^{7}$ Not to mention the huge disparity in poverty (and related physical well-being) between blacks in America and those in Africa. ${ }^{8}$ As in so many other aspects of the "anti-racist" craze, the tendency is to see only the worst in America, while ignoring comparable or far worse problems in other societies.

\section{“Art” vs. "Craft"}

To “decenter Whiteness" and "Western aesthetics" in art education, Acuff advises teachers to reject the distinction between "[fine] art" and "craft"-a distinction allegedly "connected to ... Whiteness and patriarchy." In truth, however, much the same distinction is functionally implicit in cultures the world over. As I've noted in prior work, cross-cultural studies show that the major art forms designated as "fine" in the West (painting and sculpture, among others) are universally employed to express a culture's core values. ${ }^{9}$ In that connection, Afrofuturists should read Susan Mullin Vogel's Baule: African Art / Western Eyes (1997). She notes that the Baule people of West Africa, for example, value their private devotional sculptures known as "spirit figures" much more highly than the many decorative utilitarian objects they create. As Vogel reports:

6 Basquiat: Rage to Riches, PBS, American Masters, https://www.pbs.org/wnet/americanmasters/masters/ jean-michel-basquiat/. When one considers Basquiat's work Dos Cabezas-a crudely scrawled portrait of himself and Andy Warhol gushed over as "absolutely stunning" by Warhol biographer Bruno Colacello in the film-it renders featuring him as a "master" artist utterly ludicrous.

7 Abdi Latif Dahir, "Africa Is Again the World's Epicenter of Modern-Day Slavery," QuartzAfrica, March 1, 2019, https://tinyurl.com/vtxe9nvu.

8 According to the World Bank, 40 percent of the Sub-Saharan African population were living in extreme poverty in 2018. https://tinyurl.com/yzysmoad. In 2019, the poverty rate for blacks in the U.S. had dropped below 20 percent. https://tinyurl.com/2nxtjsje.

9 Who Says That's Art? A Commonsense View of the Visual Arts (Pro Arte Books, 2014), 27-32. 
Baule artists and householders have created a profusion of useful objects decorated with exceptional care and skill.... In Baule life these objects, far more elaborate than the ordinary ones, are amusing, delightful to behold, and, as I was often told, "will make people talk about you," but they are devoid of spiritual power, and Baule people finally consider them trivial.

Moreover, Vogel (a highly respected authority on African art) maintains that her findings on Baule art and culture are broadly applicable to other African societies.

\section{The New Brand of Racism: 2044 and CRT}

Rolling and Acuff were panelists in the first of four webinars titled The 2044 Series: Anti-Racist Praxis as Futurist Art Pedagogy, sponsored by the Onstead Institute for art and design education at the University of North Texas. Their session, nominally devoted to “Anti-Racist Pedagogy in Art Education,” instead offered a new brand of racism. The series title was inspired by black law professor Bennett Capers's “Afrofuturism, Critical Race Theory and Policing in the year 2044." Though published in the New York University Law Review - a "leading academic law journal" committed to promoting influential legal "scholarship" (which presumably deals with facts) - the Capers screed is a work of pure speculation. Yet another instance of the total debasement of academic standards.

In the article, Capers imagines what policing and life might look like in 2044, when people of color are projected to constitute the majority. What solution does he envision to reverse the crucial breakdown of the black family? His only reference to the problem is a footnote citing an article by Ta-Nehisi Coates dealing with the destructive consequences of "mass incarceration"10_but downplaying the underlying problem of criminal activity by black men. However, Capers reassures us that sexual assault crimes, for instance, will be reduced by "the widespread availability of sex robots, the legalization of sex work, and the move towards positive sex norms." In addition, domestic violence will also decline-thanks in part to "the availability of housing and employment, thus facilitating the ease with which individuals can enter and exit unwanted relationships." Capers also looks forward to a time when government will be able

10 Ta-Nehisi Coates, "The Black Family in the Age of Mass Incarceration," The Atlantic, October 2015, https://tinyurl.com/ybj6u8n2. 
“to record, store, and analyze nearly everything people do," since it will greatly reduce the use of police force-though he does admit that for many people "this future may seem dystopian, suggesting . . . George Orwell's 'big brother' run amok.” Indeed.

Capers relies heavily on Critical Race Theory (CRT)—which he summarizes as

arguing that a preference for neutral, disengaged, unraced, and unsexed voices in legal scholarship reifies a baseline that is both white and male. To challenge this preference, Critical Race Theory embraces the notion of "grounding a scholarly voice in the material, aesthetic, emotional, and spiritual experiences of people of color."

The poisonous implication of such reasoning is that the various experiences of the races differ essentially, rather than superficially-that we therefore do not share a common humanity. Thus it is profoundly racist at its core.

\section{Divisive Consequences}

The pernicious assumptions of CRT lead to such divisive nonsense as an emotionally intense conversation about the "aesthetics of racism" by Acuff and Amelia Kraehe (a professor of art and visual culture education in the University of Arizona's College of Fine Arts ${ }^{11}$ in the March 2021 issue of Art Education. In it, Acuff laments that the childhood ordeal of having her hair straightened "to look 'prettier" greatly affected how she defined beauty. It would no doubt surprise her to know that I-as a "white supremacist," merely by the fact of having been born white, according to CRT-went to similar lengths in the 1950s to have my hair curled, and even fantasized looking like Liat, the Polynesian beauty in the musical South Pacific. Nonetheless, Acuff's essentially racist take on hair styles was echoed by two other black professors of art education (one from Arkansas Tech University, the other from University of North Texas) in a session on "Hair as Metaphor for Power, Identity, and Agency” in the 2021 NAEA Convention. Judging from the enthusiastic comments of many who viewed the session, we can expect more racially charged "art" education along these lines.

Still more racially divisive are the guiding assumptions of Deborah Filbin, an earnest “White middle-class teacher” in a Title 1 school on Chicago's South

11 Note the conceptual slippage in the inclusion of "visual culture education" in the College of Fine Arts. 
Side. ${ }^{12}$ She is deeply troubled by guilt for her "White privilege," though she never states what that consists of. To escape the practice of teaching from a "Whitemale Eurocentric perspective," however, this well-meaning teacher embraces scrapping lesson plans and welcomes student input.

Most revealing is a piece by one of her students on the subject of crime in Chicago. It boldly depicts a gun being held to the head of a black youth. Significantly, the hand holding the gun is also black. In a related piece of graphic art titled Do Black Lives Matter? the same student penned the words "Black lives matter only if a White man take[s] one.” A message very different from the one being peddled by James Rolling.

Filbin's article focuses on "unpacking [her] White privilege.” But she would do better to attend to unpacking that student's astute observation. If she did so, the crucial underlying truth might emerge. Black lives lost to black-on-black crime do not matter in the public debate because they don't fit the dominant narrative that systemic anti-black racism is the root of all evil.

\section{Which Black Artists Should Matter?}

In selecting exemplary artists for study, art educators obsessed with black victimhood would do well to take a lesson from the life of young Jewish Holocaust survivors whose story is told in the moving BBC docudrama The Windermere Children (screenplay by Simon Block)-about a British project to rehabilitate a cohort of concentration camp survivors on an idyllic estate in England's Lake District. Before their re-entry into the larger world, these youngsters are sagely advised not to dwell on their status as victims.

Do not seize whatever you want because you feel your suffering entitles you to it. Instead, earn your place in the world, and you will earn selfrespect, and the respect of others. Be proud of who you are. Of what you have overcome. And be open to the wonders that life can offer, even as you struggle with the darkest of thoughts, and memories. Especially then.

In that light, I would urge greater discretion in the selection of black artists to teach about. At present, art educators focus on examples conveying messages of black victimhood and marginalization, with little or no regard for the work's

12 Deborah Filbin, "Discovering How Black Lives Matter: Embracing Student Voice in the Art Room," Art Education (January 2021), 19-25. 
quality, depth, or moral compass. The mere blackness of the artists and their subjects is paramount. Instead, teachers should consider which work offers a more edifying vision of the black experience-Basquiat's crude graffiti and the demeaning caricatures by Michael Ray Charles and Kara Walker now featured in art education? Or the ennobling embodiments by more traditional artists such as Charles White, Elizabeth Catlett, and Augusta Savage? A chance remark by a black fellow visitor to the Augusta Savage exhibition at the New-York Historical Society in 2019 is germane here. What he especially liked, he said, was the fact that Savage hadn't depicted her subjects as "victims."13

Although Savage, White, and Catlett-all of whom were active during a time of far more widespread and challenging racism than the present-sometimes dealt with racially fraught subjects such as lynching, they mainly created images projecting the strength, courage, and beauty of their fellow blacks. In addition, rather than conjuring up fictional African superheroes like Black Panther (the eponymous hero of the 2018 film directed by Ryan Coogler, lauded by Afrofuturists), they represented notable figures from their American past, real-life heroes in the struggle against slavery and racism such as Harriet Tubman and Frederick Douglass. In so doing, they demonstrated that they were proud of who they were and of what they and other blacks had overcome. For them, there were far more significant aspects of identity than their hair styles. Wouldn't their example better serve students, both black and white, than that of the jaded and blinkered "anti-racist" postmodernists now featured in art education?

13 Savage will be featured in a forthcoming issue of Aristos, www.aristos.org. 